
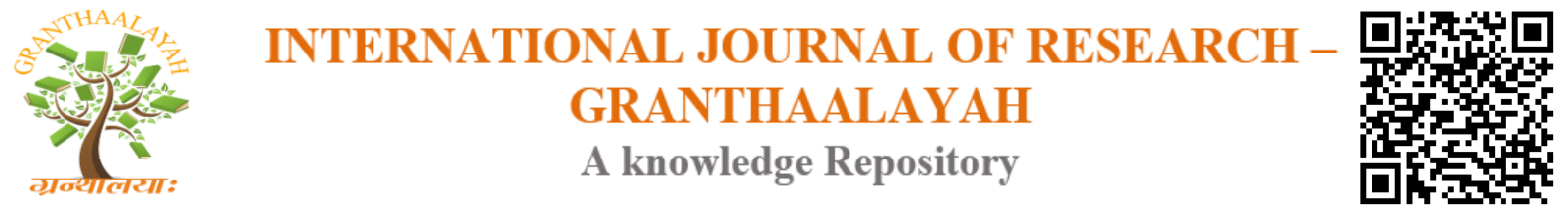

Management

\title{
SOCIO - ECONOMIC DETERMINANTS OF HOUSEHOLDS FUEL CONSUMPTION IN NIGERIA
}

\author{
Abdullahi Buba ${ }^{* 1}$, Musa Abdu ${ }^{1}$, Idi Adamu ${ }^{2}$, Adamu Jibir ${ }^{3}$, Yusuf Isah Usman ${ }^{4}$ \\ ${ }^{* 1}$ Assistant Lecturer, Department of Economics, Gombe State University, Nigeria \\ ${ }^{2}$ Graduate Assistant, Department of Economics, Gombe State University and Postgraduate \\ Student, University of Jos \\ ${ }^{3} \mathrm{PhD}$ Scholar, University of Colombo \\ ${ }^{4}$ Postgraduate Student, Usman Danfodio University Sokoto
}

\begin{abstract}
Attainment of universal access to affordable, reliable, sustainable and modern energy is one of the goals for Sustainable Development Goals (SDGs). Existing data and statistic suggest that high proportion of households in less developed countries heavily rely on solid fuels for domestic requirements. Also, recent data revealed that in Nigeria over 70 percent of households depend on fuel wood for cooking which indicate the task ahead of policy makers in the country for ensuring access to efficient sources of energy before the expiration of sustainable development goals. In this study we empirically examined socio-economic factors that influence households' likelihood of energy consumption in Nigeria. In order to achieve our specific objectives, we adopt 2013 demographic health survey dataset for Nigeria and multinomial logistic regression was conducted in analyzing the factors affecting households' decision for energy demand. Evidence from the study revealed that demographic characteristics, economic status, public awareness and social variables are strong determinants of households' energy choice in the country and conformed to the propositions of "Energy Ladder Hypothesis". We concluded by presenting concluding remarks and policy implications for decision making toward ensuring access to affordable, sustainable and efficient energy in Nigeria.
\end{abstract}

Keywords: Energy; Sustainable Development; Environmental Degradation; Energy Ladder Model; Nigeria.

Cite This Article: Abdullahi Buba, Musa Abdu, Idi Adamu, Adamu Jibir, and Yusuf Isah Usman. (2017). "SOCIO - ECONOMIC DETERMINANTS OF HOUSEHOLDS FUEL CONSUMPTION IN NIGERIA." International Journal of Research - Granthaalayah, 5(10), 348-360. https://doi.org/10.29121/granthaalayah.v5.i10.2017.2312.

\section{Introduction}

It is estimated that globally 3 billion people depend on solid fuels (biomass and coal) to meet their domestic needs (Staton \& Harding, 2000) and in developing countries about 2.5 billion 
people rely on these unclean fuels for their domestic requirements (International Energy Agency, 2006). The statistic according to IEA report is likely to increase to 2.7 billion by the 2030 . This alarming rate at which the number of people who depend on fuel wood as their major source of energy particularly in developing countries led to the assertion of potentially devastating depletion of forest resources (Arnold \& Persson, 2003) which will eventually lead to global environmental degradation.

In Nigeria, the proportion of households that consume solid fuels for domestic needs is estimated to be 70 percent consisting 86 percent of rural households and 42 percent of urban households respectively (Gwatkin, Rutstein, Johnson, Pande \& Wagstaff, 2000). Similarly, the Energy Commission of Nigeria in its 2003 report estimated that over 60 percent of Nigerian population depends on fuel wood for cooking and other domestic uses. However, in the year 2013 the proportion of Nigerian households that consumes fuel wood for cooking escalated to about 72 percent as put forward by National Population Commission and ICF International (2014).

This huge and growing numbers of people in the country led to the conclusion that the nation's 15 million hectares of forest and woodland resources could be depleted within the next fifty years (Energy Agency Commission, 2003). The scenario would degenerate not just to deforestation, but also lead to environmental effects, health effects and conservation effects. The combine effects would jeopardize chances of attainment of the nation's developmental needs and aspirations as agricultural land that can derive diversification agenda in the country could be destroy and hamper human capital development adversely. To mitigate against ill fate associated with the continues uncontrolled fuel wood consumption, there is need to ascertain forces that induce its consumption in the country. Thus, this paper is therefore aim to empirically examine the factors that influence households demand for fuel wood against clean and efficient other sources of energy in Nigeria. The specific objectives of the study are to:

i. examine influence of demographic characteristics on likelihood of household choice for energy in Nigeria;

ii. investigate influence of economic status on likelihood of household choice for energy in Nigeria;

iii. ascertain influence of public campaigns on likelihood of household choice for energy in Nigeria; and

iv. Examine influence of social factors on likelihood of household choice for energy in Nigeria.

The paper is structured in to five sections. Following this introduction is conceptual issues and literature review and methodological techniques presented in sections two and three respectively. Presentation and discussion of results was presented in section four while section five presents conclusions and policy implications.

\section{Conceptual Issues and Literature Review}

\subsection{Effects of Fuel Wood Consumption}

Production and consumption of almost any type of energy have environmental impacts. Harvesting of fuel wood, in particular, contributes to deforestation, soil erosion, and 
desertification. In Nigeria, harvesting of fuel wood contributes to deforestation at a rate of about 400,000 hectares per year (Oladosu \& Adegbulugbe, 1994. If this trend continues the country's forest resources could be completely depleted by 2020. Use of fuel wood as an energy source can also contribute to the accumulation of $\mathrm{CO} 2$, the main greenhouse gas, both because burning fuel wood produces $\mathrm{CO} 2$, and because deforestation destroys an important $\mathrm{CO} 2$ sink (Oladosu \& Adegbulugbe, 1994). In addition, use of biomass fuel for cooking is a major cause of health problems in developing countries due to indoor air pollution (Bruce et al. 2000; and Ezzati \& Kammen 2001). For example, the world health organization (WHO) estimates that 1.5 million premature deaths per year are directly attributed to indoor air pollution from the use of solids fuels (IEA, 2006). Use of biomass in traditional stoves exposes the users, mainly woman and children, to high levels of indoor air pollution (Dzioubinski \& Chipman 1999). Recognizing the adverse effect of use of traditional biomass fuels, the United Nations Millennium Project recommends halving the number of households that depends on traditional biomass for cooking by 2015, which involves about 1.3 billion people switching to other fuels (IEA, 2006). The effects of fuel wood consumption vary according to a range of factors including the country, feedstock and end use. Thus, some of the likely effects of fuel wood consumption include but not limited to environmental effects, health effects and conservative effects.

\subsection{Empirical Literature}

Empirical evidences based on energy demand studies reveal that both energy ladder hypothesis and fuel stacking hypothesis have been confirmed. For example, Rajmohan \& Weerahewa (2007) investigated household energy consumption patterns of urban, rural and estate sectors in Sri Lanka. The results show that the energy ladder hypothesis holds for Sri Lanka and the country as a whole is moving towards modern fuels such as liquefied petroleum gas (LPG) and electricity. The urban sector proceeds much faster than the rural sector. Mekonnen \& Kohlin (2009) examined the determinants of household fuel choice and demand in major Ethiopian cities. The study found widespread use of multiple fuels for a particular purpose (such as cooking) suggestive of fuel stacking rather than energy ladder. The evidences show that higher kerosene prices made households choose either solid fuels (charcoal and wood) only or a mix of solid and non-solid fuels (wood, charcoal, kerosene and electricity).

Energy demand and poverty related issues have been investigated by several studies using different methodologies and estimation techniques. Pachauri \& Spreng (2004) observed that access to more efficient energy sources implies high level of energy consumption associated with enhanced level of energy use which will generate other benefits such as improved indoor air quality, more time for productive or recreational activities and time freed from collecting biomass energy. It is instructive to note that access alone does not provide sufficient information that can be used to draw conclusions regarding wellbeing. For instance, some households that use only biomass and other less efficient energy sources but use sufficient quantities of these sources might be considered better off than others that have access to more efficient energy sources but cannot consume adequate amounts of such efficient energy sources. Thus to improve the wellbeing of the poor, two elements are needed with regard to energy: improve access to efficient energy sources and ensure adequate consumption of such energy sources by making them affordable. 
Jackson (2005) showed that the number of people living on less than $\$ 2$ per day tends to decrease sharply when access to electricity is guaranteed. The study found a strong correlation between modern energy consumption and Gross National Product (GNP) per capita. Indeed, it showed that GNP tends to increase rapidly as commercial energy use per capita increases, mainly for low income countries. When the countries reach a high level of per capita GNP, factors such as efficient utilization of energy by industries, energy production and transformation systems tend to make the difference for economic growth to continue so that more energy consumption for a country no longer implies more income for the country. Robic et al. (2010) revealed that Tajikistan suffered from acute case of energy poverty where people lacked both physical access to energy and the ability to afford it. The study provided an overview of energy poverty situation in Tajikistan and recommended that a provision of three kilowatts per household for the most vulnerable group would result in significant benefits that would overall poverty alleviation for the country.

Furthermore, Dzioubinski \& Chipman (1999) showed that the household sector accounts for 15 to 25 per cent of primary energy use in developed countries and a higher share in developing countries. A huge gap remains between household energy use in developed and developing countries. Increase in energy-based living standards and more efficient energy use are major opposing trends in developed countries that affect household energy consumption. Diffusion of energy efficient technologies for cooking, heating, lighting, electrical appliances, and building insulation in developing countries have been slow. The study also indicated that government policies designed to influence household energy consumption are often contradictory, with mixed results. Barnes et al (1996) found that the use of both traditional (biomass energy burned in conventional stoves) and modern (electricity and kerosene) sources improve household consumption and income; the return on modern sources is 20 to 25 times higher than that on traditional sources. In addition, after comparing alternate measures of the energy poverty line, they observed that some per cent of rural households in Bangladesh were energy poor compared to 45 per cent that were income poor. The findings implied that growth in electrification and adoption of efficient cooking stoves for biomass use can lower energy poverty in a climatefriendly way by reducing carbon dioxide emissions. The study concluded that reducing energy poverty helps in reducing income poverty as well.

Demurger \& Fournier (2011) used descriptive statistics from the household survey carried out in ten villages in Labagoumen Township in northern China to analyse the general dependence of households upon forest resources as well as energy consumption patterns in the studied villages. The study used the probit model to determine the marginal effects of various socio-economic variables on coal consumption. It observed that income is a key factor in explaining energy use and fuel substitution. It also noted that wealth is a significant and negative determinant of household firewood consumption. Further evidence on the relationship shows that at the top of the wealth distribution, there may be some floor effect in decreasing firewood consumption and that moving away from traditional ways of cooking may not be so easy in an area, even with improved living standards. Wealthier households may not be rich enough to afford changing stoves or may still be reluctant to change their traditional cooking and heating habits. Besides the income effect, the analysis also shows the importance of own-price effect in explaining firewood consumption behavior. The opportunity cost of firewood collection was found to be significant and negative for the wealthiest group of households indicating that the price effect gains 
importance with rising incomes. Modernization in the form of increasing education or family network is also found to be a key factor in the energy consumption behavior, especially when dealing with energy source switching behavior.

Ouedraogo (2006) used multinomial log it model to analyze the factors determining urban household energy preferences for cooking in Ouagadougou. The analyses show that the inertia of household cooking energy preferences are due to poverty factors such as low income, households' poor access to electricity for primary and secondary energy uses, low housing standards and household size. The utilization rates of firewood decrease from low income households to households with higher incomes. The marginal effects of "household income" are not significant for firewood and charcoal. The marginal effect of "primary education level" is significant at one per cent level and with sign: when this variable changes from higher education level to primary education, the probability of using firewood as main cooking energy increases by 0.61 per cent. The household size, cooking habits and formal education level of household heads have significant effects on wood energy preferences.

Lee (2013); and Svoboda \& Badr (2013) used Ordinary Least Square (OLS) regression to assess determinants of household electricity consumption. Variables like; temperature, electric water heater, electric clothes dryer, dish washer, number in house, family income, age of respondents, nature of employment, municipality of residence, expenditure per capita, private water connection, price of kerosene, age of household head, gas price, were found to be positively significant related to the household consumption of electricity. While factors such as; price of electricity, change of temperature, second and third quarter period of the year, pleasure consumption of wood, household perception of wood consumption, time when the dwelling was built, level of education of the household head, public water source and fire wood price, were found to have a negative relationship with the amount of household consumption of electricity. Koshal et al. (1999) used the same OLS model to examine the determinants of kerosene in Indonesia. The study obtained significant negative value for the price elasticity and significant positive value of the income elasticity of kerosene, which implies that it is a normal good in Indonesia. Also, the cross elasticity with respect to price of electricity was found to be positive implying that kerosene and electricity are substitute commodities to some extent. On the other hand, Osiolo (2010) used the same OLS method to examine the determinants of fuel wood expenditure in Kenya. Only age of the household head and the level of the education of the household head, were found to have positive significant relationship with household fuel wood expenditure.

Furthermore, Nlom \& Karimove (2014); Eakins, (2013); and Mensah \& Adu (2013) applied ordered logit and probit models to examine the factors that influence household energy choice to more cleaner source, variables such as; income, firewood price, education level of household head, share of dwelling with other people, urban household, access to Liquefied Petroleum Gas (LPG) were found to have a positive relationship with the probability of adopting more cleaner energy. While other variables, such as; electricity price, price of kerosene, age of the household head, household size, gender (male) of the household head, and access to fire wood, have negative effect on the probability of the use of clean and efficient fuels. 
From the existing literature, many studies were conducted in both developed and developing countries on household energy consumption. These studies however, have some identified limitations based on the scope covered, model used, the variables included in the study among others. For instance, some studies on household energy consumption like Svoboda \& Badr, 2013; Pourazarm \& Cooray, 2013; and Auffhammer \& Aroonruengsawat, 2012 focused only on electricity aspect of household energy consumption, thereby neglecting other aspects; like consumption of fuel wood and other solid fuels, households' consumption of kerosene, as well as liquefied natural gas as a source of household energy consumption. Also some studies Naibbi \& Healey, 2013; and Onoja \& Emodi, 2011 focused only on fuel wood analysis as a source of house hold energy neglecting other aspects like; kerosene, electricity gas and transportation respectively. Moreover, from the literature reviewed, it was shown that not all factors have equal important in determining the pattern and behaviour of household energy consumption for different areas due to differences in socio-economic settings, environmental factors, and cultural factors as well as the average level of development in the area.

\subsection{Energy Ladder Model}

The energy ladder hypothesis is one of the most common conceptualizations of energy use dynamics among households. It postulates that low income households generally use traditional stoves and cooking fuels such as animal dung, charcoal and wood, while those households with higher income used modern cooking technology and fuels. As income increases, households transit from traditional fuels and cooking stoves to modern fuels and cooking technology (Baldwin, 1986; Smith, 1987; Leach, 1992). Furthermore, the literature on household energy demand and choice has shown that households in transition (that is, those between low income and high income) consume transition fuels such as charcoal and kerosene. While low income households use biomass fuels, higher income households consume energy that is cleaner and more expensive such as liquefied petroleum gas and electricity (Hosier \& Dowd, 1987; Barnes \& Floor, 1999; and Heltberg, 2005).

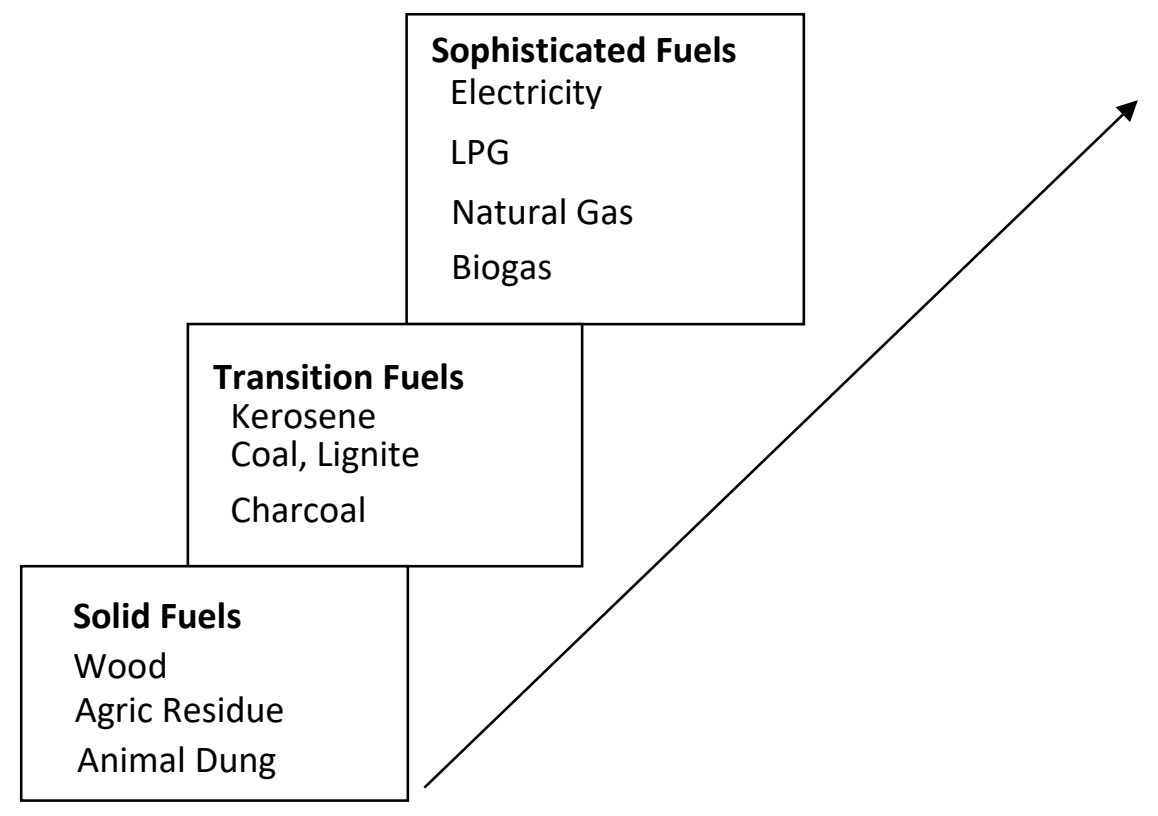

Figure 1: Energy Ladder Model 
The energy ladder hypothesis is predicated on the economic theory of consumer behaviour (Hosier \& Kipondya, 1993). However, when income increases, households not only consume more of the same good they also shift to more sophisticated goods with higher quality. Thus the theoretical assumption underlying the energy ladder hypothesis is that low living standards induce greater dependence on firewood and other biomass fuels owing to a combination of income and substitution effects (Baland et al., 2007). Furthermore, the energy ladder hypothesis assumes that cleaner fuels are normal economic goods while traditional fuels are inferior goods (Rajmohan \& Weerahewa, 2007; and Demurger \& Fournier, 2011).

Thus, the energy-ladder hypothesis emphasizes the role of income in determining fuel choices. However, it appears to imply that a move up to a new fuel is simultaneously a move away from previously used fuel(s). Mekonnen \& Köhlin (2009) suggest the idea of an energy-demand ladder where it is argued that, as incomes rise, households' demand for fuel is guided by the nature of appliances used and that fuel choice and demand depends on the purpose for which energy is required. More recently, it has been argued that households in developing countries do not switch to modern energy sources but instead tend to consume a combination of fuels which may include combining solid fuels with non-solid fuels as sources of energy.

Hence, instead of moving up the ladder step by step as income rises, households choose different fuels as from a menu (Mekonnen \& Köhlin, 2009). They may choose a combination of high-cost and low-cost fuels, depending on their budgets, preferences and needs (World Bank, 2003). This led to the concept of fuel stacking (multiple fuel use) as opposed to fuel switching or an energy ladder (Masera et al., 2000; and Heltberg, 2005). The reasons for multiple fuel use are varied and not dependent on economic factors alone although the affordability or cost of the energy service also has an important bearing on households' choices. In some cases, households use more than one fuel because they want to increase the security of supply. In other cases, the choice is dependent on cultural, social or taste preferences (Pachauri \& Spreng, 2004).

\section{Methodology}

\subsection{Sources of Data}

This study used 2013 Demographic and Health Survey (DHS) for Nigeria. The survey was conducted by National Population Commission (NPC) and ICF International (2014) which covered the entire population residing in non-institutional dwellings units in the country. The survey adopted cluster sampling frame of Enumeration Areas (EAs) used for 2006 population census in Nigeria. The dataset was selected using a stratified three-stage cluster design comprising a total of 904 clusters, 372 in urban areas and 532 in rural areas and a sample of 40,680 households were randomly selected for the survey.

\subsection{Statement of Hypothesis}

To achieve the major and specific objectives of the study, the following hypothesis were tested:

1) Ho: Demographic characteristics do not influence likelihood of household choice for energy in Nigeria.

2) Economic status does not influence likelihood of household choice for energy in Nigeria. 
3) Public campaigns do not influence likelihood of household choice for energy in Nigeria.

4) Social factors do not influence likelihood of household choice for energy in Nigeria.

\subsection{Model Specification}

To achieve the specific objectives raise in section one of this paper, we estimated the model that examines choice between a set of mutually exclusive sources of energy in Nigeria. Thus, the following model was specified as:

$$
\operatorname{Pr}\left[Y_{i}=J\right]=\frac{\exp \left(\beta_{\mathrm{j}} \mathrm{X}_{\mathrm{i}}\right)}{\sum_{k=0}^{5} \exp \left(\beta_{\mathrm{k}} \mathrm{X}_{\mathrm{i}}\right)}---------------
$$

Where:

$\operatorname{Pr}\left[Y_{i}=J\right]$ is the likelihood of choosing either electricity, or natural gas, or kerosene, or charcoal, $\mathrm{J}=0$ is fuel wood as the reference category,

$\mathrm{x}_{\mathrm{i}}=\mathrm{is}$ a vector of exogenous variables, $\beta_{\mathrm{j}}=$ is a vector of the estimated parameters.

\subsection{Method of Data Analysis}

Both descriptive analysis (where applicable) and econometric analysis were conducted in the study. Basically, descriptive statistic was used to describe distribution of households' choice for energy consumption in Nigeria. In conducting the econometric analysis, the paper used discrete choice models rather than classical regression analysis. This is because, the study entails qualitative response and the dependent variable in the model is a non-continues variable. Thus, the assumptions of conventional regression break down and consequently ordinary least square (OLS) method might not be appropriate in the analysis of such discrete choice models (Wooldridge, 2002; Baum, 2006; Cameron \& Trivedi, 2009; and Greene, 2013).

\section{Presentations and Discussions of Result}

In this section, we begin the empirical analysis by presenting the distribution of households' choice for energy in Nigeria. This was done by employing simple descriptive statistic analysis; thereafter the empirical household fuel consumption function was estimated using the multinomial logistic model.

Table 1: Distribution of Households Choice for Cooking Fuel in Nigeria, 2013

\begin{tabular}{lll}
\hline Type of Fuel & Freq. & Percentage \\
\hline Electricity & 172 & 0.45 \\
LPG & 282 & 0.74 \\
Natural Gas & 484 & 1.26 \\
Biogas & 89 & 0.23 \\
Kerosene & 7599 & 19.84 \\
Coal, lignite & 100 & 0.26 \\
\hline
\end{tabular}




\begin{tabular}{lll}
\hline Charcoal & 1200 & 3.13 \\
Wood & 27644 & 72.18 \\
Agric Residue & 730 & 1.91 \\
\hline
\end{tabular}

Source: Authors' Computation, Using 2013 (DHS)

Statistic for households' choice for cooking fuel in Nigeria as presented in table 1 revealed that about 76 percent of the sampled households depend largely on solid fuels. It further revealed that about 72 percent of the respondents used fuel wood against other alternative sources of energy for cooking. This may be influence not only by the availability of forest in the country, rather, prevalence of incidence of poverty in Nigeria.

Table 2: Result of Multinomial Estimates of Households Consumption for Fuel in Nigeria (Reference Group=Fire Wood), 2013

\begin{tabular}{|c|c|c|c|c|}
\hline $\begin{array}{l}\text { Independent } \\
\text { Variables }\end{array}$ & Electricity & Natural Gas & Kerosene & charcoal \\
\hline \multirow{2}{*}{ AgeHH } & .0554 & $-.0757 * * *$ & $-.0848 * * *$ & -.0024 \\
\hline & (.0514) & $(.0244)$ & $(.0088)$ & $(.0152)$ \\
\hline \multirow{2}{*}{ AgeHH2 } & $-.0011^{*}$ & $.0004 *$ & $.0005^{* * *}$ & -.0003 \\
\hline & $(.0006)$ & $(.0002)$ & $(.0000)$ & $(.0002)$ \\
\hline \multirow[t]{2}{*}{ Female } & -.1017 & $-.2646^{*}$ & $.1208^{* * *}$ & -.0730 \\
\hline & $(.2095)$ & $(.1426)$ & (0524) & $(.0853)$ \\
\hline \multirow{2}{*}{ HHSize } & $-.2208 * * *$ & $-.1278 * * *$ & $-.1639 * * *$ & $-.0769 * * *$ \\
\hline & $(.0398)$ & $(.0220)$ & $(.0087)$ & $(.0118)$ \\
\hline \multirow[t]{2}{*}{ Heduc } & $.6035 * * *$ & $1.2465^{* * *}$ & $.1848 * * *$ & $-.1038 * * *$ \\
\hline & $(.1261)$ & (.0909) & $(.0297)$ & $(.0404)$ \\
\hline \multirow[t]{2}{*}{ Wealth } & $3.7338 * * *$ & $5.7430 * * *$ & $2.6354 * * *$ & $1.1837 * * *$ \\
\hline & (.2669) & $(.4602)$ & $(.0435)$ & $(.0555)$ \\
\hline \multirow{2}{*}{ Radio } & $-.7803 * * *$ & $-.4759 * * *$ & $-.6395 * * *$ & $-.2381 * * *$ \\
\hline & $(.2328)$ & $(.1738)$ & $(.0604)$ & $(.0891)$ \\
\hline \multirow[t]{2}{*}{$\mathbf{T v}$} & $-1.1992 * * *$ & $-.8677 * * *$ & $-.6200 * * *$ & $-.5661 * * *$ \\
\hline & $(.3552)$ & $(.3318)$ & $(.0697)$ & $(.1009)$ \\
\hline \multirow[t]{2}{*}{$\mathrm{NE}$} & $-3.0536 * * *$ & $-3.6786 * * *$ & $-2.8810 * * *$ & $1.4646 * * *$ \\
\hline & $(.5431)$ & $(.3461)$ & $(.1133)$ & $(.1832)$ \\
\hline \multirow[t]{2}{*}{ NC } & -.1930 & $-1.1664 * * *$ & $-1.3864 * * *$ & $1.5015^{* * *}$ \\
\hline & $(.2179)$ & $(.1488)$ & $(.0731)$ & $(.1756)$ \\
\hline \multirow[t]{2}{*}{ NW } & $-2.6465 * * *$ & $-1.9318 * * *$ & $-1.2952 * * *$ & $.4795^{* *}$ \\
\hline & $(.5466)$ & $(.2606)$ & $(.1131)$ & $(.2157)$ \\
\hline \multirow[t]{2}{*}{ SE } & $-2.2042 * * *$ & $-2.9765 * * *$ & $-1.5537 * * *$ & $-1.0768 * * *$ \\
\hline & $(.3854)$ & $(.2383)$ & $(.1167)$ & $(.2942)$ \\
\hline \multirow[t]{2}{*}{ SW } & -1.2716 *** & $-1.2445^{* * *}$ & -.0642 & $.6387 * * *$ \\
\hline & $(.3270)$ & $(.1925)$ & $(.0911)$ & $(.1928)$ \\
\hline \multirow[t]{2}{*}{ Rural } & $-.4890 * *$ & $-1.2927 * * *$ & $-.7983 * * *$ & $-.8407 * * *$ \\
\hline & (.2001) & $(.1602)$ & $(.0501)$ & $(.0810)$ \\
\hline \multirow[t]{2}{*}{ Igbo } & $.5106^{* *}$ & $.8979 * * *$ & $.4245^{* * *}$ & $.8387 * * *$ \\
\hline & $(.2763)$ & $(.1729)$ & $(.1053)$ & $(.2001)$ \\
\hline Hausa & $1.0307 * * *$ & $.5858^{* * *}$ & -.1576 & $.4633 * * *$ \\
\hline
\end{tabular}




\begin{tabular}{|c|c|c|c|c|}
\hline & $(.3540)$ & $(.2540)$ & $(.1105)$ & $(.1306)$ \\
\hline \multirow[t]{2}{*}{ Yoruba } & $.7632 * * *$ & $.7370 * * *$ & $.6583 * * *$ & $2.1881 * * *$ \\
\hline & $(.2463)$ & $(.1728)$ & $(.0832)$ & $(.1072)$ \\
\hline \multirow[t]{2}{*}{ Constant } & $-18.3320 * * *$ & $-26.6889 * * *$ & $-6.4072 * * *$ & $-6.4757 * * *$ \\
\hline & (1.5316) & $(2.3034)$ & $(.2446)$ & $(.4120)$ \\
\hline Observations & 36903 & 36903 & 36903 & 36903 \\
\hline Pseudo $\mathbf{R}^{2}$ & 0.5126 & 0.5126 & 0.5126 & 0.5126 \\
\hline
\end{tabular}

Source: Authors' Computation, Using 2013 (DHS)

Estimates from the households fuel consumption function presented in table 2 revealed that demographic characteristics, economic status, public campaign (awareness), social factors are strong determinants that influence the likelihood of households decision for fuel consumption in Nigeria. Evidence from the study also concurred with the theoretical propositions of the study as almost all the coefficient of estimates included in the model have expected signs (with the exception of coefficient of awareness).

Empirical result from the study as presented in table above indicates that the coefficient of age square suggest that as the age of household head reached certain level he/she will be more likely to use alternative sources of energy (natural gas and kerosene) than the fuel wood for cooking. This implies that there is a particular age bracket that when reached household heads are more conscious about the disastrous effects associated with incessant consumption of fuel wood. Hence, he/she will use his/her life time savings (or retirement benefits) for consumption of the sophisticated energy sources. The higher the level of education attained by household head the greater chances for his/her willingness to consume alternative sources of energy for domestic purposes. This suggests that educated household heads are less likely to engage in consuming fuel wood, hence, reduces the tendencies of environmental degradation through deforestation in search for energy.

The result also shows that as one's economic status increases he/she is less likely to partake in discriminate destruction of natural vegetation for energy consumption. This implies that fuel wood is mostly patronized by those who fall below the socio-economic status threshold and conformed to the theoretical propositions pursued in the study. Further, the empirical evidence revealed that the major ethnic groups in the country have more chances of using alternative sources of energy than fuel wood over the minority ethnic groups in the country. This may be due to the perceived greater advantage in favour of these major ethnic groups by the Nigerian minority ethnic groups in terms of socio-economic status in the country. However, female headed household and the south western region as well as the 3 northern geo political zones have more probabilities of consuming kerosene and charcoal over male headed household and household from the oil rich (Niger Delta) region.

On the other hand, result from the study portrays that, when control for age (i.e age square) a household head is less likely to use electricity rather than fuel wood for domestic purpose. This may be due to the fact that there is risks associated with electricity consumption, especially, taking the nature of electricity supply and distribution in Nigeria in to cognisance. Coefficient of 
estimate from the study also indicates that an increase in household size is positively related with the probabilities of using fuel wood over efficient sources of energy. This means that given the household level of income, an increase in its members can expose the household to a certain degree of poverty. Subsequently, the household can find it difficult to meet with its energy consumption demand and inevitably, the household has to resort to fuel wood consumption due to its affordability and/or proximity.

In addition, the finding depicts that increase in public campaigns (awareness) against indiscriminate destruction of forest is associated with more likelihood for fuel wood consumption rather than the alternative sources of energy. Though, this empirical finding is against theoretical expectation. But, the result may be influence by the fact that most people that owned radio or TV sets don't tuned and/or pay attention to the enlightment campaigns against indiscriminate destruction of forest, instead, are likely preoccupied by listening or watching social programs or movies. In furtherance, north east, north west, south east, and south west geo political zones and households residing in rural areas have more probabilities of using fuel wood over alternative energy sources than the households from oil rich (Niger Delta) geo political zone as well as those residing in the urban areas of the country. Thus, the result is in agreement with the energy ladder theory because, economic wellbeing is relatively higher in south-south region due to localization of petroleum companies and economic activities normally flourish in urban areas than the rural areas as well.

\section{Conclusions and Policy Implications}

Our findings presented above suggest that households' demographic characteristics strongly influence likelihood of household choice for energy consumption in Nigeria. To effectively reduce discriminate destruction of forest for fuel wood consumption in the country there is need for vigorous policy toward reduction of incidence of poverty through provision for social security insurance scheme, and adoption of policy that will improve the living condition of the vulnerable groups (female headed households).

Secondly, economic status is also found to be strong variant that influences likelihood of household choice for energy consumption in the country. To effectively redirect households' preference for energy toward environment friendly alternative sources of energy, there is need for government at all tiers of governance to invest its resources in the education sector of the economy with view of enhancing access to affordable and quality education outcomes as well as ensure equitable and balance distribution of economy's pie which will go a long way empowering different groups.

Thirdly, public campaigns are discovered to be crucial forces in influencing the likelihood of households decision as regard energy consumption (though with undesirable signs) in Nigeria. It is pertinent for all relevant ministries, departments, and agencies to restrategise its public awareness campaigns against environmental and ecological risks associated with discriminate destruction of natural vegetation and emphasizing importance of consuming efficient energy sources. 
Finally, social forces are strong determinants that influence likelihood of households' choice for energy consumption in the country. There is need therefore for the state to increase its public allocation on infrastructures with view of enhancing regional balance resource allocation and diversifying the country's potentials in agriculture, mining and manufacturing sectors of the economy. Also, action plans that would transform rural areas need to be put in motion through provision of basic social amenities that would guarantee sustainable development.

\section{References}

[1] Arnold, M., \& Persson, R. (2003). Reassessing the fuelwood situation in developing countries. International Forestry Review 5(4), 379-383.

[2] Auffhammer, M., \& Aroonruengsawat, A. (2012). Simulating the impacts of climate change, prices and population on California's residential electricity demand. Energy Institute at Haas WorkingPaper Series 208R.

[3] Baland, J., Bardhan, P., Das, S., Mookherjee, D., Sarkar, R. (2007). Managing the environmental consequences of growth: Forest degradation in the Indian Mid-Himalayas. India Policy Forum, 3, 215-277.

[4] Baldwin, S. (1986). Biomass stoves: Engineering design, development and dissemination. Arlington:VITA.

[5] Barnes, F., \& Floor, M. (1996). Rural energy in developing countries: A challenge for economic development. Annual Review of Energy and Environment. 21: 497-530.

[6] Baum, C. F. (2006). An introduction to modern econometrics using Stata.Texas: StataCorp LP.

[7] Bruce, N., Perez-Padilla, R., \& Albalak, R. (2000). "Indoor air pollution in developing countries: A major environmental and public health challenge," Bulletin of the World Health Organization 78:1078-1092.

[8] Cameron, A. C., \& Trivedi, P. K. (2009). Microeconometrics using Stata. Texas: StataCorp LP.

[9] Demurger, S., Fournier, M. (2011), Poverty and Firewood Consumption: A Case Study of Rural Households in Northern China. China Economic Review, 22(4), 512-523.

[10] Dzioubinski, O., \& Chipman R. (1999). Trends in consumption and production: Household energy consumption. Discussion Paper of the United Nations Department of Economic and Social Affairs Pp 21

[11] Eakins, J. (2013). An analysis of the determinants of household energy expenditures: Empirical evidence from the Irish household budget survey, PhD Thesis. University of Surrey, UK.

[12] Energy Commission of Nigeria (2003): National Energy Policy. Federal Republic of Nigeria, Abuja.

[13] Ezzati, M., \& Kammen, D.M. (2001). Indoor air pollution from biomass combustion and acute respiratory infections in Kenya: An exposure-response study, The Lancet 358 (9282): 619-24.

[14] Greene, W. H. (2013). Econometric Analysis, 5th Edition. New York: Pearson Education, Inc.

[15] Gwatkin DR, Rutstein S, Johnson K, Pande RP, Wagstaff A. (2000). Socio-economic differences in health, nutrition, and population. HNP/Poverty Thematic Group. Washington, D.C.: World Bank.

[16] Horsier, R. \& Kipondya, W. (1993): Urban household energy use in Tanzania: Prices, substitution and poverty. Energy Policy, 453-473.

[17] Hosier, R. H., \& Dowd, J. (1987). Household fuel choice in Zimbwawe: An empirical test of the energy ladder hypothesis. Resources and Energy, 9: 347-61.

[18] International Energy Agency (2006). World Energy Outlook, Paris OECD

[19] Jackson, T. (2005), Motivating sustainable consumption: A review of evidence on consumer behaviour and behavioural change. A report submitted to the Sustainable Development ResearchNetwork. 
[20] Koshal, K., Koshal, M., \& Boyd, G. (1999). Demand for kerosene in developing countries: A case study of Indonesia. Journal of Asian Economics 10, 329-336.

[21] Leach, G. (1992). The energy transition. Energy Policy, 20(2): 116-123.

[22] Lee, L.Y. (2013). Household energy mix in Uganda. Energy Economics 39, 252-261.

[23] Masera, O.R., Saatkamp, B.D., Kammen, D.M. (2000). From linear fuel switching to multiple cooking strategies: A critique and alternative to the energy ladder model. World Development, 28(12), 2083-2103.

[24] Mekonnen, A., \& Kohlin, G. (2009). Determinants of households fuel choice in major cities in Ethiopia. Working Papers in Economics No. 399.

[25] Mensah, T., \& Adu, G. (2013). An empirical analysis of household energy choice in Ghana. Uppsala Working Paper Series No. 6.

[26] Munasinghe, M. (1992). Energy policies for sustainable growth in developing countries. Harvard International Review 14(2), 25-28.

[27] Naibbi, A.I., Healey, R.G. (2013). Northern Nigeria's dependence on fuel wood: Insights from nationwide cooking fuel distribution data. International Journal of Humanities and Social Science 3, 160-173.

[28] National Population Commission (NPC) [Nigeria] \& ICF International. (2014). Nigeria

[29] Demographic and Health Survey 2013. Abuja, Nigeria, Rockville, Maryland, USA: NPC and ICF International.

[30] Nlom, J.H., Karimov, A.A. (2014). Modeling fuel choice among households in Nnaji, C., Ukwueze, E., Chukwu, J. (2012). Determinants of household energy choices for cooking in rural areas: Evidence from Enugu State, Nigeria. Continental Journal of Social Sciences 5, 2141-4265. Northern Cameroon. WIDER Working Paper Series 2014/038. 45.

[31] Oladosu, G.A; \& Adegbulugbe, A.O. (1994), Nigeria's household energy sector: Issues and Supply/Demand Frontiers. Energy Policy 22(6): 538-549.

[32] Onoja, A.O. (2012). Econometric analysis of factors influencing fuel wood demand in rural and peri-urban farm households of Kogi State, 8, 115-127.

[33] Osiolo, H. (2010). Enhancing household fuel choice and substitution in Kenya.

[34] Ouedraogo B. (2006). Household energy preferences for cooking in urban Ouagadougou, Burkina Faso, Energy Policy.

[35] Pachuari, S. and Spreng, D. (2004). Energy use and energy access in relation to poverty. Economic and Political Weekly, 39(3), 271-278.

[36] Pourazarm, E., \& Cooray, A. (2013). Estimating and forecasting residential electricity demand in Iran. Economic Modeling, 35, 546-558.

[37] Rajmohan, K., Weerahewa, J. (2007). Household Energy Consumption Patterns in Sri Lanka. Sri Lanka Journal of Agricultural Economics, 9(1), 55-77.

[38] Robic, S., Olshanskaya, M., Vrbensky, R., Morvaj, Z. (2010). Understanding energy povertyCase study of Tajikistan. Retrieved on 05/02/2013 from http://www.ffydd.org/documents/congresspapers/339.pdf

[39] Smith, K. (1987). The Biofuel Transition. Pacific and Asian Journal of Energy, 1(1), 13-32.

[40] Staton D. M, \& Harding, M. H. (2000). Health and environmental effects of cooking stove use in developing countries.

[41] Svoboda, P., \& Br, J. (2013). Electricity consumption demand model in Czech households, 6364.

[42] Wooldridge, J. M. (2002). Econometric Analysis of Cross-Section and Panel Data. Cambridge: The MIT Press.

[43] World Bank (2003). Household Energy Use in Developing Countries, a Multicountry Study, UNDP/World Bank Energy Sector Management Assistance Programme (ESMAP)

*Corresponding author.

E-mail address: abdulmaikano85@gmail.com 